\title{
In vitro propagation and cell suspension culture of Callistemon citrinus $\mathrm{L}$.
}

\author{
R.S. David Paul Raj ${ }^{1}$, Sheena Michael Morais ${ }^{2}$ and K. Gopalakrishnan ${ }^{1}$ \\ ${ }^{1}$ Center for Research and Development, PRIST University, Thanjavur, Tamilnadu, India. \\ ${ }^{2}$ Dept. of Biotechnology, School of Bioengineering, SRM University, Kattankulathur, Chennai, India. \\ dpaulraj1976@gmail.com
}

\begin{abstract}
The bottle brush tree, Callistemon citrinus is a shrub that is nearing extinction. An attempt to revive this plant and propagate it in vitro has been performed for large scale production. Calli cultured on MS medium with different combinations of cytokinins and auxins viz. $1.0 \mathrm{mg} / \mathrm{l} \mathrm{Kinetin}$ along with $1.0 \mathrm{mg} / \mathrm{l} \mathrm{IAA} ; 1.5 \mathrm{mg} / \mathrm{l} \mathrm{Kinetin}$ along with $1.0 \mathrm{mg} / \mathrm{l}$ IAA; $1.0 \mathrm{mg} / \mathrm{l} \mathrm{Kinetin}$ along with $1.0 \mathrm{mg} / \mathrm{I} \mathrm{IBA}$, and $2.0 \mathrm{mg} / \mathrm{l} \mathrm{Kinetin}$ along with $1.5 \mathrm{mg} / \mathrm{IBA}$. All combinations were very effective in inducing callus. $0.5 \mathrm{mg} / \mathrm{l} \mathrm{kinetin}$ along with $0.5 \mathrm{mg} / \mathrm{IAA}$ was very effective for shoot regeneration and shoot elongation. The developed shoots when transferred to MS medium, supplemented with $1.5 \mathrm{mg} / \mathrm{l}$ IBA, shows root development within a week. Axillary bud proliferation is also observed in the explants inoculated in MS medium supplemented with combinations of kinetin and IAA.
\end{abstract}

Keywords: Callistemon citrinus, Indole Acetic Acid (IAA), Indole Butyric Acid ((IBA), Benzyl amino purine(BAP).

Introduction
The bottle brush tree, Callistemon citrinus is a shrub

belonging to the family, Myrtaceae. The synonym of the plant is $C$. lanceolatus. Due to the over exploitation for its volatile oils and secondary metabolites, there is a need to develop alternate strategies for conservation and industrial production of bioactive compounds from this plant (Vogler et al., 1998). The leaf of the plant is used as a tea substitute and it has a refreshing flavor too. The standardized oil from the leaves of $C$. citrinus has been proved to have anti-nociceptive and anti-inflammatory effects in experimental animals (Sudhakar et al., 2004). The oil of $C$. citrinus stimulates the analgesic activity with aspirin and pentazocine. The oil reduces the paw volume in case of paw edema. Many phenolic compounds and cross reactive allergenic components have been identified in this plant (Stanaland et al., 1986; Mahmoud et al., 2002). The essential oils from $C$. citrinus exhibit higher activity than the synthetic antibiotics like miconazole and clotrimazole (Brophy et al., 1998; Sharma et al., 2006). The plant has been proved to exhibit anticandidal activity (Dutta et al., 2007). Studies have also proved that the methanol extract of the plant has anti-thrombin activity (Chistokhodova et al., 2002).

C. citrinus has a phytotoxin (leptospermone) belongs to the family of $\beta$ -

Research article

CIndian Society for Education and Environment (iSee)
Fig. 1. Callus development with $2 \mathrm{mg} / \mathrm{l}$ kinetin \& $1.5 \mathrm{mg} / \mathrm{IAA}$; Fig.2. Shoot regeneration with $1 \mathrm{mg} / \mathrm{l}$ kinetin \& $1 \mathrm{mg} / \mathrm{I} I B A$; Fig. 3. Root regeneration with $1.5 \mathrm{mg} / \mathrm{I} I \mathrm{BA}$;

Fig.4. Axillary bud proliferation with $2 \mathrm{mg} / \mathrm{l}$ kinetin \& $1 \mathrm{mg} / \mathrm{IIAA}$

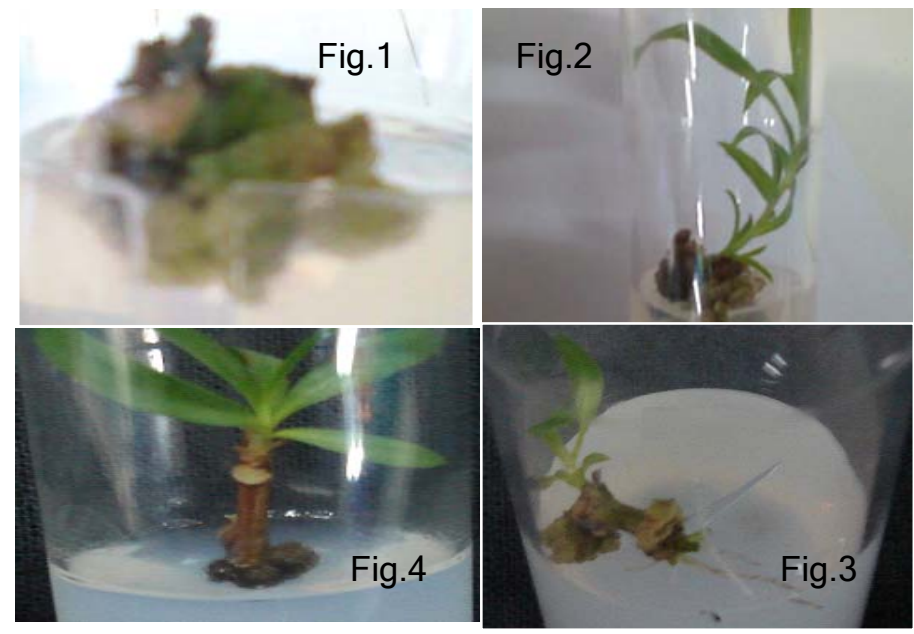

Growth in MS medium

"In vitro propagation of Callistemon citrinus. L" http://www.indjst.org
Materials and Methods

Medium and hormone preparation

MS supplemented with sucrose $(30 \mathrm{~g} / \mathrm{l})$ and agar $(8 \mathrm{~g} / \mathrm{l})$ at $\mathrm{pH} 5.8$ was used for the in vitro propagation of $C$. citrinus. The various hormone combinations used for the study of callogenic response are given in the Table 1.

Surface sterilization of explants

The explants (leaf, stem, axillary bud) were washed thoroughly with tap water for $10 \mathrm{~min}$, then washed with two drops of tween- 20 followed by a wash with distilled water for $10 \mathrm{~min}$. The leaves were Indian J.Sci.Technol. 
then cut into small pieces of 1.0 $\mathrm{cm}^{2}$. The stems and axillary buds were cut to $1 \mathrm{~cm}$ in height. These explants were treated with $70 \%(\mathrm{v} / \mathrm{v})$ ethanol for 20 sec. The leaves were then washed with $0.1 \% \quad(\mathrm{w} / \mathrm{v})$ mercuric chloride for $15-20 \mathrm{sec}$, then 35- $40 \mathrm{sec}$ for stems and finally, $50 \mathrm{sec} \mathrm{min}^{-1}$ for axillary buds. The explants were washed thoroughly thrice with distilled water and wiped dry with sterile Whatmann no. 1 filter paper prior to inoculation.

Inoculation

The medium was autoclaved at $1.06 \mathrm{~kg} / \mathrm{cm}^{2}$ at a temperature of $121^{\circ} \mathrm{C}$ for $15 \mathrm{~min}$. The required quantity of filter sterilized hormones was amended with medium kept in culture tubes. The surface sterilized explants were aseptically inoculated on the medium kept in the culture test tubes and incubated at $25 \pm 1^{\circ} \mathrm{C}$ with 3000 lux intensity cool white light region. After the development of shoot, the shoots were excised into single shoot and transferred to MS medium supplemented with 1.5 $\mathrm{mg} / \mathrm{l}$ IBA for rooting.

\section{Cell suspension culture}

Approximately $0.1 \mathrm{~g}$ of callus, which still in its active growth phase (i.e., after the $15^{\text {th }}$ day of subculture), was placed in $250 \mathrm{ml}$ flasks containing $100 \mathrm{ml}$ liquid MS medium supplemented with 1.0 $\mathrm{mg} / \mathrm{l} \mathrm{kinetin}$ and $1.0 \mathrm{mg} / \mathrm{l}$ Indole acetic acid (IAA). Cultures were incubated in $25^{\circ} \mathrm{C}$ in a horizontal shaker at $100 \mathrm{rpm}$ for 21 days. Growth of cells were then determined by measuring absorbance at $600 \mathrm{~nm}$, fresh weight, dry weight and hemocytometer reading were taken at every 3 days.

Number of generations, $n=\left(\log X-\log X_{0}\right) \times 3.32$

Where, $X$ represents number of cells $/ \mathrm{ml}$ at the end of log phase and Xo represents that at the start. Multiplication rate, $r$ (generations/ hour), $r=n /\left(t_{1}-t_{0}\right)$. Generation time, $\mathrm{g}$ (hours) $=1 / \mathrm{r}$. Specific growth rate, $\mu\left(\right.$ hour $\left.^{-1}\right)=0.693 / \mathrm{g}$.
Vol. 3 No. 1 (Jan 2010)

ISSN: 0974- 6846
Table 1. List of hormone combinations used for callus induction, axillary bud proliferation and shoot regeneration in MS medium

\begin{tabular}{|l|l|l|l|l|}
\hline $\begin{array}{c}\text { Hormone } \\
\text { combinations }\end{array}$ & $\begin{array}{l}\text { Conc. } \\
(\mathrm{mg} / \mathrm{l})\end{array}$ & $\begin{array}{l}\mathrm{S} . \\
\text { No }\end{array}$ & $\begin{array}{l}\text { Hormone } \\
\text { combinations }\end{array}$ & $\begin{array}{l}\text { Conc. } \\
(\mathrm{mg} / \mathrm{l})\end{array}$ \\
\hline $\mathrm{K}+\mathrm{IAA}$ & $0.5 / 0.5$ & 23 & $\mathrm{~K}+\mathrm{IBA}$ & $2.0 / 1.5$ \\
$\mathrm{~K}+\mathrm{IAA}$ & $0.6 / 0.5$ & 24 & $\mathrm{~K}+\mathrm{IBA}$ & $2.0 / 2.0$ \\
$\mathrm{~K}+\mathrm{IAA}$ & $0.7 / 0.6$ & 25 & $\mathrm{~K}+2,4-\mathrm{D}$ & $0.5 / 0.5$ \\
$\mathrm{~K}+\mathrm{IAA}$ & $0.9 / 0.5$ & 26 & $\mathrm{~K}+2,4-\mathrm{D}$ & $1.0 / 0.5$ \\
$\mathrm{~K}+\mathrm{IAA}$ & $0.9 / 1.1$ & 27 & $\mathrm{~K}+2,4-\mathrm{D}$ & $1.0 / 1.0$ \\
$\mathrm{~K}+\mathrm{IAA}$ & $0.9 / 1.8$ & 28 & $\mathrm{~K}+2,4-\mathrm{D}$ & $1.5 / 0.5$ \\
$\mathrm{~K}+\mathrm{IAA}$ & $0.9 / 3.5$ & 29 & $\mathrm{~K}+2,4-\mathrm{D}$ & $1.5 / 1.0$ \\
$\mathrm{~K}+\mathrm{IAA}$ & $1.0 / 1.0$ & 30 & $\mathrm{~K}+2,4-\mathrm{D}$ & $2.0 / 0.5$ \\
$\mathrm{~K}+\mathrm{IAA}$ & $1.0 / 0.5$ & 31 & $\mathrm{~K}+2,4-\mathrm{D}$ & $2.0 / 1.0$ \\
$\mathrm{~K}+\mathrm{IAA}$ & $1.5 / 0.5$ & 32 & $\mathrm{~K}+2,4-\mathrm{D}$ & $2.0 / 1.5$ \\
$\mathrm{~K}+\mathrm{IAA}$ & $2.0 / 0.5$ & 33 & $\mathrm{~K}+2,4-\mathrm{D}$ & $2.0 / 2.0$ \\
$\mathrm{~K}+\mathrm{IAA}$ & $2.0 / 1.0$ & 34 & $\mathrm{BAP}+\mathrm{IAA}$ & $0.5 / 0.5$ \\
$\mathrm{~K}+\mathrm{IAA}$ & $2.0 / 1.5$ & 35 & $\mathrm{BAP}+\mathrm{IAA}$ & $0.6 / 0.5$ \\
$\mathrm{~K}+\mathrm{IAA}$ & $2.0 / 2.0$ & 36 & $\mathrm{BAP}+\mathrm{IAA}$ & $0.7 / 0.5$ \\
$\mathrm{~K}+\mathrm{IAA}$ & $1.5 / 1.0$ & 37 & $\mathrm{BAP}+\mathrm{IAA}$ & $0.9 / 0.5$ \\
$\mathrm{~K}+\mathrm{IBA}$ & $0.5 / 0.5$ & 38 & $\mathrm{BAP}+\mathrm{IAA}$ & $0.9 / 1.1$ \\
$\mathrm{~K}+\mathrm{IBA}$ & $1.0 / 0.5$ & 39 & $\mathrm{BAP}+\mathrm{IAA}$ & $0.9 / 1.8$ \\
$\mathrm{~K}+\mathrm{IBA}$ & $1.0 / 1.0$ & 40 & $\mathrm{BAP}+\mathrm{IAA}$ & $0.9 / 3.5$ \\
$\mathrm{~K}+\mathrm{IBA}$ & $1.5 / 0.5$ & 41 & $\mathrm{BAP}+\mathrm{IAA}$ & $1.0 / 1.0$ \\
$\mathrm{~K}+\mathrm{IBA}$ & $1.5 / 1.0$ & 42 & $\mathrm{BAP}+\mathrm{IAA}$ & $2.0 / 1.0$ \\
$\mathrm{~K}+\mathrm{IBA}$ & $2.0 / 0.5$ & 43 & $\mathrm{BAP}+\mathrm{IBA}$ & $3.0 / 1.0$ \\
$\mathrm{~K}+$ IBA & $2.0 / 1.0$ & 44 & $\mathrm{BAP}+\mathrm{IBA}$ & $4.0 / 2.0$ \\
\hline
\end{tabular}

Table 2. Hormone combinations for callus induction in MS medium (Callus initiation observed after 3 weeks)

\begin{tabular}{|c|c|c|c|c|}
\hline $\begin{array}{l}\text { Hormone } \\
\text { combinations }\end{array}$ & $\begin{array}{l}\text { Conc. } \\
(\mathrm{mg} / \mathrm{l})\end{array}$ & $\begin{array}{l}\text { S. } \\
\text { No }\end{array}$ & $\begin{array}{l}\text { Hormone } \\
\text { combinations }\end{array}$ & $\begin{array}{l}\text { Conc. } \\
(\mathrm{mg} / \mathrm{l})\end{array}$ \\
\hline $\mathrm{K}+\mathrm{IAA}$ & $0.5 / 0.5$ & 16 & $\mathrm{~K}+\mathrm{IBA}$ & $1.5 / 1.0$ \\
\hline $\mathrm{K}+\mathrm{IAA}$ & $0.6 / 0.5$ & 17 & $\mathrm{~K}+\mathrm{IBA}$ & $2.0 / 0.5$ \\
\hline $\mathrm{K}+\mathrm{IAA}$ & $0.7 / 0.5$ & 18 & $\mathrm{~K}+\mathrm{IBA}$ & $2.0 / 1.0$ \\
\hline $\mathrm{K}+\mathrm{IAA}$ & $0.9 / 1.1$ & 19 & $\mathrm{~K}+\mathrm{IBA}$ & $2.0 / 1.5$ \\
\hline $\mathrm{K}+\mathrm{IAA}$ & $0.9 / 1.8$ & 20 & $\mathrm{~K}+\mathrm{IBA}$ & $2.0 / 2.0$ \\
\hline $\mathrm{K}+\mathrm{IAA}$ & $0.9 / 3.5$ & 21 & $K+2,4-D$ & $0.5 / 0.5$ \\
\hline $\mathrm{K}+\mathrm{IAA}$ & $1.0 / 1.0$ & 22 & $K+2,4-D$ & $1.0 / 0.5$ \\
\hline $\mathrm{K}+\mathrm{IAA}$ & $1.5 / 0.5$ & 23 & $K+2,4-D$ & $1.5 / 1.0$ \\
\hline $\mathrm{K}+\mathrm{IAA}$ & $1.5 / 1.0$ & 24 & $\mathrm{~K}+2,4-\mathrm{D}$ & $2.0 / 1.5$ \\
\hline $\mathrm{K}+\mathrm{IAA}$ & $2.0 / 0.5$ & 25 & $B A P+I A A$ & $0.5 / 0.5$ \\
\hline $\mathrm{K}+\mathrm{IAA}$ & $2.0 / 1.0$ & 26 & BAP + IAA & $0.7 / 0.5$ \\
\hline $\mathrm{K}+\mathrm{IAA}$ & $2.0 / 1.5$ & 27 & $\mathrm{BAP}+\mathrm{IAA}$ & $0.9 / 0.5$ \\
\hline $\mathrm{K}+\mathrm{IAA}$ & $2.0 / 2.0$ & 28 & $B A P+I A A$ & $1.0 / 1.0$ \\
\hline $\mathrm{K}+\mathrm{IBA}$ & $1.0 / 0.5$ & 29 & $\mathrm{BAP}+\mathrm{IBA}$ & $4.0 / 2.0$ \\
\hline $\mathrm{K}+\mathrm{IBA}$ & $1.0 / 1.0$ & & & \\
\hline
\end{tabular}

\section{Results and discussion Callus induction}

Surface sterilized explants on induction gave callus after a period of 3 weeks. The various hormone combinations (Table 1) that gave callus induction are listed in Table 2. Among the hormone combinations, $1.0 \mathrm{mg} / \mathrm{l}$ kinetin along with $1.0 \mathrm{mg} / \mathrm{IAA}$, $1.5 \mathrm{mg} / \mathrm{l}$ kinetin along with 1.0 $\mathrm{mg} / \mathrm{l} \mathrm{IAA}, 1.0 \mathrm{mg} / \mathrm{l}$ kinetin and $1.0 \mathrm{mg} / \mathrm{l} \mathrm{IBA}$, and $2.0 \mathrm{mg} / \mathrm{l}$ kinetin along with $1.5 \mathrm{mg} / \mathrm{l}$ IBA were highly effective in inducing callus (Fig. 1). Callus was found to be fragile and white in colour initially and as the incubation days increased the callus colour changed to pale white colour and become little hardened.

\section{Shoot regeneration}

Shoot was induced from the callus (Fig. 2). The hormone combinations that initiated shoot are presented in Table 3 . The increase in the length of the shoot system as well as the number of leaves was monitored during this period. It was observed that $0.5 \mathrm{mg} / \mathrm{l}$ kinetin along with $0.5 \mathrm{mg} / \mathrm{l} \mathrm{IAA}$ was very effective for shoot regeneration and shoot elongation. There was a geometrical increment in the length and number of leaves (from 2 to 8), within a period of 3 months in the developed shoots.

\section{Root induction}

The developed shoots were transferred to MS medium supplemented with $1.5 \mathrm{mg} / \mathrm{l}$ IBA. Root induction was initiated within a period of one week

(Fig. 3). The total number of roots obtained was five and few secondary root initiations were obtained during the period of three months.

\section{Axillary bud proliferation}

Axillary bud proliferation was effective with different combinations of kinetin (K) and IAA (Table 4, Fig. 4).

\section{Cell suspension culture}

When callus was placed in liquid culture they disperse easily into clumps of $0.5-5.0 \mathrm{~mm}$. Further
Research article

CIndian Society for Education and Environment (iSee)
"In vitro propagation of Callistemon citrinus. L" http://www.indjst.org
Paulraj et al. Indian J.Sci.Technol. 
agitation leads to fragmentation of these clumps into small cell aggregates. The parameters that are associated with cell growth are presented in Table 5. The growth curve of cell suspension culture derived from callus exhibited three different stages:

(i) lag phase $0-6^{\text {th }}$ day, (ii) log phase $\left(6^{\text {th }}-18^{\text {th }}\right.$ day) and (iii) stationary phase $\left(18^{\text {th }}-24^{\text {th }}\right.$ day) (Fig. 5). The doubling time is substantially reduced in cell suspension cultures.

\section{Discussion}

The present research work is a first attempt towards the micropropagation of $C$. citrinus when compared with other species like $C$. viminalis and $C$. rigidus. For the induction of callus, it was observed that kinetin along with IAA and Kinetin along with IBA showed significant results ie. $0.5 \mathrm{mg} / \mathrm{l}$ kinetin along with $0.5 \mathrm{mg} / \mathrm{l} \mathrm{IAA} ; 1.0 \mathrm{mg} / \mathrm{l}$ kinetin and $1.0 \mathrm{mg} / \mathrm{l} \mathrm{IBA}$ when compared with hormone combinations for callus induction from C. viminalis (Lin che et al., $2005)$. In case of $C$. rigidus $\mathrm{BAP}$ $(1.5 \mathrm{mg} / \mathrm{l})$ and NAA $(0.5 \mathrm{mg} / \mathrm{l})$ was found to be the best suitable hormone combination for callus induction when compared to kinetin and IAA in C. citrinus (Cheng hou et al., 2007).

Table 4. List of hormone combinations that induced axillary bud proliferation in MS medium

\begin{tabular}{|l|c|l|l|}
\hline $\begin{array}{l}\text { Hormone } \\
\text { combinations }\end{array}$ & $\begin{array}{c}\text { Conc. } \\
(\mathrm{mg} / \mathrm{l})\end{array}$ & $\begin{array}{l}\text { Period } \\
\text { for initiation }\end{array}$ & $\begin{array}{l}\text { Shoot } \\
\text { length* }(\mathrm{cm})\end{array}$ \\
\hline $\mathrm{K}+\mathrm{IAA}$ & $0.5 / 0.5$ & 1 month & $0.7 \pm 0.2$ \\
\hline $\mathrm{K}+\mathrm{IAA}$ & $1.5 / 1.0$ & 1 month & $0.5 \pm 0.1$ \\
\hline $\mathrm{K}+\mathrm{IAA}$ & $2.0 / 1.0$ & 1 month & $1.5 \pm 0.1$ \\
\hline $\mathrm{BAP}+\mathrm{IAA}$ & $4.0 / 2.0$ & 1 month & $1.2 \pm 0.1$ \\
\hline
\end{tabular}

*Shoot length measured after 1 month of inoculation of explants in MS medium for further research in different aspects on the biosynthesis of secondary metabolites of $C$. citrinus.

\section{References}

1. Brophy JJ, Goldsack RJ, Forster $\mathrm{PI}$, Craven LA and Lepschi BJ (1998) The leaf essential oils of the Australian members of the genus Callistemon (Myrtaceae). J. Essen. Oil Res. 10(6), 595- 606.

2. Chistokhodova N, Nguyen C, Calvino T, Kachirskia I and Cunningham G (2002) Antithrombin activity of medicinal plants from central Florida. J. Ethnopharma. 81(2), 277-280.

3. Dutta BK, Karmakar S, Naglot A, Aich JC and Begam M (2007) Anticandidial activity of some essential oils of a mega biodiversity hotspot in India. Mycoses. 50 (2), 121-124.

4. Mahmoud II, Moharram FA, Marzouk MS, Linscheid MW and Salch MI (2002) Polyphenolic constituents of Callistemon

lanceolatus leaves. Pharmazie. 57(7), 494-496.
5. Lin Che, Pei FU, Wu Lin-sen and Shen Pei-fu (2005) Micropropagation of Callistemon viminalis. J. Fuji Fore. Sci. Technol. 32(1), 52-54.

6. Sharma RK, Kotoky R and Bhattacharya PR (2006) Volatile oil from the leaves of Callistemon lanceolatus D.C. grown in northeastern India. Flav. Frag. J. 21(2), 239-240.

7. Stanaland BF, Gennaro RN, Sweeney MJ and White RS (1986) Isolation and characterization of Effective Auxillary bud proliferation was obtained with the hormone combinations of Kinetin and IAA similar to callus induction when compared to BAP in Callistemon rigidus (Lin che et al., 2005).

Leptospermone is considered as an unusual cyclic sesquiterpene present in $C$. citrinus (Vogler et al., 1998).The present study on cells suspension culture of C. citrinus uoens the possibility of production of the secondary metabolite leptospermone under in vitro conditions for industrial production (Ying Wang, 2008). Cell suspension cultures from the callus led to a decrease in the generation time and an increase in the metabolic production. Innovative biotechnologies in plant cell and tissue cultures, and the latest achievements in metabolic engineering to improve the production sustainability and efficiency of plant derived pharmaceuticals is highly needed for industrial production of secondary metabolites in future. This is a first attempt to study on cell suspension culture of $C$. citrinus for secondary metabolite (Leptospermone) production. This has provided a unique opportunity

Research article

(CIndian Society for Education and Environment (iSee)
Table 5. Growth parameters of cell suspension culture

\begin{tabular}{|l|l|}
\hline \multicolumn{1}{|c|}{ Parameters } & \multicolumn{1}{c|}{ Value } \\
\hline Generations, $\mathrm{n}$ & 4 \\
\hline Multiplication rate, $\mathrm{r}$ & $\begin{array}{l}0.016825 \pm 0.0017 \\
\text { generations hour- } 1\end{array}$ \\
\hline Generation time & $60 \pm 6$ hours \\
\hline Specific growth rate & $0.0114+0.0009$ hour-1 1 \\
\hline $\begin{array}{r}0.1 \mathrm{~g} \text { callus inoculated in } 100 \mathrm{~m} / \text { liquid } \mathrm{MS} \\
\text { medium }\end{array}$
\end{tabular}

"In vitro propagation of Callistemon citrinus. L" http://www.indjst.org
Paulraj et al. Indian J.Sci.Technol. 